\title{
Failure Mode and Prediction of the Strength of Branch Attachments
}

\author{
Brian Kane, Robert Farrell, Shepard M. Zedaker, \\ J.R. Loferski, and D.W. Smith
}

\begin{abstract}
Predicting the strength of branch attachments is important for arborists and urban foresters because branch failure can cause damage and injuries. Previous studies have shown that the ratio of branch to trunk diameter is a better predictor of strength than the angle of attachment. Aside from these two factors, however, few other morphological measures of the attachment have been investigated with respect to predicting the strength of attachments. Many branch attachments from three species were broken on a testing machine and breaking stress was calculated. Prior to breaking, various morphological measures and ratios describing the attachment were made. Breaking stress varied by form of the attachment (u-shaped or v-shaped), failure mode, and the presence of included bark. The best predictor of breaking stress was the ratio of branch to trunk diameters. Results are discussed in the context of previous studies and with respect to tree risk assessment.
\end{abstract}

Key Words. Branch attachment; breaking stress; included bark; tree risk assessment.

The strength of branch attachments has been studied previously, and common themes have emerged. Of particular importance is the growing consensus that the strength of a branch attachment is best predicted by the relative size of the branch to its parent stem, which is referred to here as the "diameter ratio". Contrary to common perceptions, several investigations have shown that the angle of attachment between the branch and trunk has less influence on the strength of an attachment (MacDaniels 1932; Miller 1959; Lilly and Sydnor 1995; Gilman 2003; Pfisterer 2003; Kane 2007). Included bark has also been shown to reduce the strength of attachments (MacDaniels 1932; Smiley 2003), and its presence is often associated with large diameter ratios and narrow branch angles. Aside from diameter ratio and angle of attachment, no other characteristics of branch attachments have been carefully measured with respect to how well they predict the strength of the attachment. This is especially true of included bark, which has only been tested as a binary variable, in other words, whether included bark is present or absent (Smiley 2003).

In almost all previous investigations of the strength of branch attachments, a breaking load was applied to a branch either a short (MacDaniels 1923; Gilman 2003) or longer (Miller 1959; Lilly and Sydnor 1995; Smiley et al. 2000; Smiley 2003; Kane 2007) distance from the point of attachment. In all of these studies, either the attachment or the branch itself could fail. Consequently, the strength of attachments that did not fail (i.e., the branch failed) was only implicit.

The objectives of this study were to 1) determine the breaking stress of branches of three species of shade trees; 2) qualitatively describe failure mode in greater detail; 3) identify and examine a broad range of morphologic measures that describe the branch attachment to determine which measure(s) best predict the strength of branch attachments; and 4) quantify the effect of included bark on the strength of branch attachments.

\section{MATERIALS AND METHODS}

During July 1996, branch attachments were removed from trees of three species (Acer rubrum L., Quercus acutissima Car- ruthers, Pyrus calleryana Decne.) growing at Watkins Nursery in Midlothian, Virginia, U.S. (USDA Hardiness Zone 7b). When they were removed, trees were approximately 15 years old; trunk and branch diameter ranged, respectively, from 6.4 to $17.8 \mathrm{~cm}$ ( 2.6 to $7.1 \mathrm{in}$ ) and 1.8 to $8.4 \mathrm{~cm}$ ( 0.7 to $3.4 \mathrm{in})$; tree height ranged from 4.6 to $9.1 \mathrm{~m}$ (15.2 to $30 \mathrm{ft})$. All trees had grown narrow, upright crowns resulting from close spacing in the nursery. Attachments were taken from many trees and classified as "trunkbranch," in which a lateral branch smaller than and clearly subordinate to the vertically oriented trunk was attached to the trunk; "branch-branch," in which a second-order branch was attached to a first-order branch; or "codominants," in which two vertically oriented trunks occurred on the same tree. A tree could have more than one pair of codominant stems as long as the stems were clearly extensions of a main trunk. Although branchbranch attachments were sometimes equal in diameter at the point of attachment, they were not classified as codominants because they arose from a lateral branch instead of being an extension of a trunk. Attachments were also classified according to their form, either "u-" or "v"-shaped. Form was determined by the presence or absence of a branch bark ridge: u-shaped attachments had a branch bark ridge and v-shaped attachments did not (Figure 1).

Attachments were harvested from 75 trees ( 29 red maples, 22 callery pears, and 24 sawtooth oaks), and multiple attachments were taken from all but seven trees. Branches with decay, cracks, or other defects were not sampled. Cut ends of branches were coated with wax (Anchor-seal; U-C Coatings Corp., Buffalo, NY, U.S.) to prevent moisture loss because attachments were tested up to 45 days after removal from the nursery; the coating was reapplied as necessary to ensure that the ends remained sealed. To maintain sufficient moisture content of the wood, branch attachments were kept under a tarp, out of direct sun, and were sprayed daily with water. Subsequent analysis of moisture content revealed that all attachments had been tested in the green condition (i.e., moisture content remained above the fiber saturation point). 


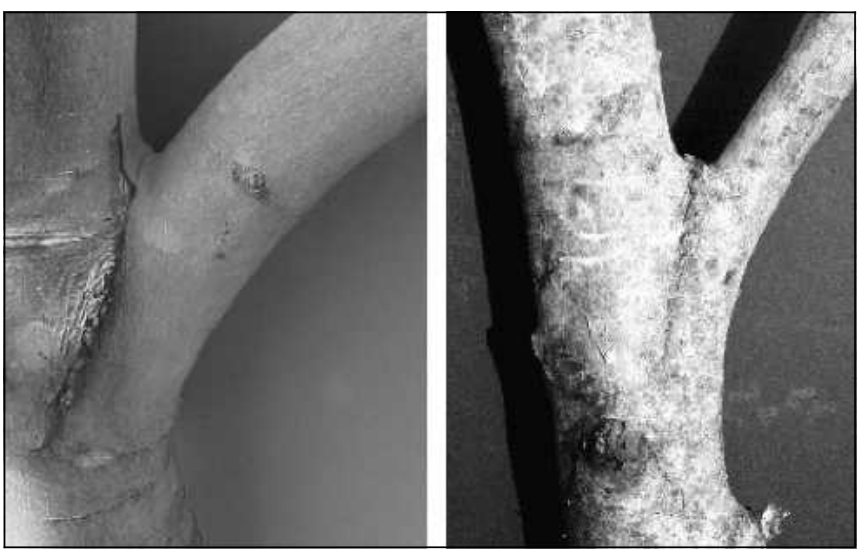

Figure 1. V-shaped (left) and u-shaped branch attachments; the branch bark ridge is clearly present in the u-shaped attachment.

Attachments were attached by chains and slip hooks to a universal testing machine (MTS, Eden Prairie, MN) $(133 \mathrm{kN}$ [30,000 lbf] capacity) and loaded at a rate of $5.1 \mathrm{~cm}$ (2 in) per minute. The rate of loading was chosen primarily out of convenience to conduct the tests in a reasonable amount of time; it was faster than the rate at which ice or snow would accrete on branches but slower than the rate at which a wind load acts. Attachments were always placed so that the larger branch (or trunk) was closer to the bed of the machine during testing (Figure 2). Bending stress $(\sigma)(\mathrm{MPa})$ was calculated in the branch cross-section as follows:

$$
\sigma=32 P \operatorname{Lsin} \theta /\left(\pi \mathrm{d}^{3}\right)
$$

where $\mathrm{P}$ is the maximum load $(\mathrm{kN}), \mathrm{L}$ is the distance $(\mathrm{m})$ between the point of application of the load and the attachment (measured parallel to the longitudinal axis of the branch), $\theta$ is the angle between the branch and the chain that secured it, and $d$ is the inside-bark branch diameter $(\mathrm{m})$. Figure 2 presents a free body diagram of the testing setup that illustrates the variables in

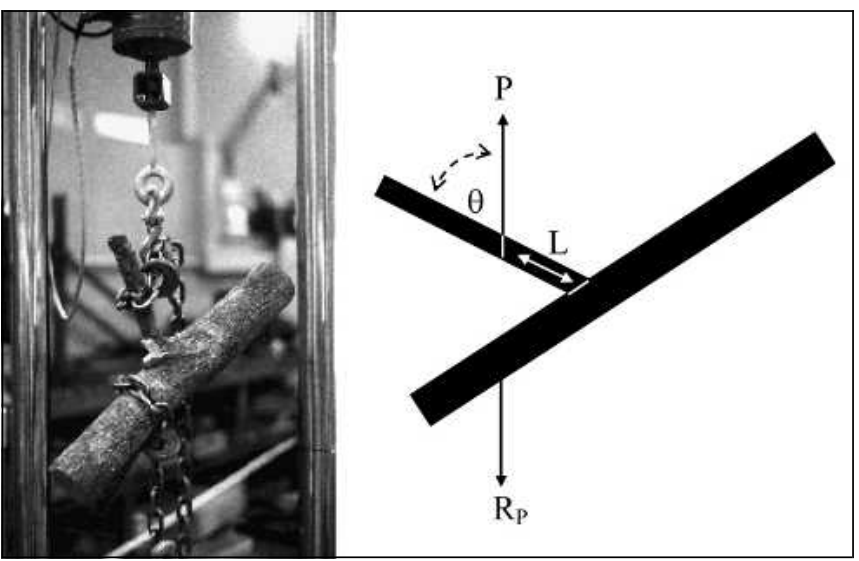

Figure 2. Image showing an attachment being pulled apart in the testing machine (left) and a free body diagram of the setup, where $P$ is the applied load; $R_{P}$ is the reaction force; $L$ is the distance from the point of applied load to the attachment, measured parallel to the longitudinal axis of the branch; and $\theta$ is the angle between the longitudinal axis of the branch and the applied load.
Equation 1. The inside-bark branch diameter was measured immediately distal to the branch collar, both parallel and normal to the applied load. If the branch collar was not obvious, diameters were measured immediately distal to the branch bark ridge. Diameters did not vary by more than $10 \%$ for almost all branches and trunks, so they were averaged and that value was used as the diameter in Equation 1. Because the load was applied close to the attachment (within $5.1 \mathrm{~cm}$ [2 in]), shear stress was also calculated for each attachment. The results for shear stress did not differ from the results for bending stress, so shear stress values have not been reported below. After breaking, a $2.5 \mathrm{~cm}$ (1 in) thick disk was taken from each branch to determine moisture content and specific gravity as described by Simpson and TenWolde (1999).

Before breaking, several morphologic characteristics and ratios that described the attachment were measured. Morphologic measures that described the branch attachment were grouped into the following three categories: angles between the branch and trunk, ratios of branch to trunk size, and dimensions of the attachment itself. All morphologic measurements are listed in Table 1, some are illustrated in Figure 3. The angle between intersecting lines parallel to the branch and the trunk was the branch angle. In some cases, however, the branch changed direction distal to the attachment, so attachment angle was also measured. This was the angle between intersecting lines parallel to the trunk and the branch at the point of attachment. For branches that did not change direction beyond the point of attachment, branch angle and attachment angle were equal. Diameter ratio was calculated as inside-bark branch diameter divided by the average of trunk diameters measured above and below the attachment. The length of the attachment was the distance from the intersection of the lines that determined attachment angle to the point on the trunk where it met the adaxial branch surface. Width of the attachment was measured as the straight-line distance below the attachment between the terminations of the branch bark ridge. Length of the branch bark ridge was measured as the straight-line distance from one end of the branch bark ridge to the center of the adaxial surface of the branch where it met the trunk. Angle of the branch bark ridge was measured at the intersection between lines parallel to the trunk and the branch bark ridge.

Failures were categorized as follows (see Figure 4): "flat surface" failures occurred when the trunk split longitudinally in half where the branch was attached; "embedded branch" failures appeared superficially similar to flat surface failures, except that wood associated with the branch separated from the trunk, leaving an obvious groove in the trunk; "ball and socket" failures (after Shigo 1985) occurred when the branch simply pulled out from the trunk, leaving the trunk mostly undamaged below the branch attachment and a hollow where the branch had been attached. After failure, the surface area of both the attachment (i.e., the exposed area after failure) and the area of included bark (if present) were measured by applying a dot grid overlaid on a tracing of the areas. The percentage of attachment area covered by included bark was the ratio of the respective areas.

A one-way analysis of variance (ANOVA) was used to determine whether breaking stress and diameter ratio varied by the type and form of the attachment, the presence of included bark, and failure mode within each species. Because sample size was unequal in some comparisons, Levene's test was used to test for homogeneity of variance within each comparison. For compari- 
Table 1. Coefficients of determination for the relationship between breaking stress and each prediction measure within each species.

\begin{tabular}{|c|c|c|c|c|c|c|c|}
\hline \multirow[b]{2}{*}{ Measure } & \multicolumn{2}{|c|}{ Red maple } & \multicolumn{2}{|c|}{ Callery pear } & \multicolumn{2}{|c|}{ Sawtooth oak } & \multirow[b]{2}{*}{ Mean $\mathrm{R}^{2}$} \\
\hline & $\mathrm{n}$ & $\mathrm{R}^{2}$ & $\mathrm{n}$ & $\mathrm{R}^{2}$ & $\mathrm{n}$ & $\mathrm{R}^{2}$ & \\
\hline Diameter ratio & 89 & 0.56 & 106 & 0.59 & 87 & 0.56 & 0.57 \\
\hline Branch diameter ${ }^{\mathrm{z}} /$ attachment width & 73 & 0.51 & 105 & 0.65 & 87 & 0.56 & 0.57 \\
\hline Trunk diameter ${ }^{\mathrm{y}} / \mathrm{attachment}$ width & 73 & 0.36 & 105 & 0.53 & 87 & 0.49 & 0.46 \\
\hline Rough branch diameter/attachment width & 73 & 0.37 & 105 & 0.40 & 87 & 0.38 & 0.38 \\
\hline Branch angle & 89 & 0.17 & 106 & 0.35 & 87 & 0.47 & 0.33 \\
\hline Branch bark ridge angle & 87 & 0.15 & 106 & 0.31 & 87 & 0.36 & 0.27 \\
\hline Trunk diameter $\mathrm{x} /$ attachment width & 71 & 0.24 & 102 & 0.02 & 87 & 0.34 & 0.20 \\
\hline Attachment length & 86 & 0.11 & 106 & 0.41 & 87 & 0.15 & 0.22 \\
\hline Attachment angle & 89 & 0.06 & 106 & 0.31 & 87 & 0.27 & 0.21 \\
\hline Branch bark ridge length & 87 & 0.11 & 106 & 0.38 & 87 & 0.13 & 0.21 \\
\hline Specific gravity & 88 & 0.01 & 106 & 0.01 & 87 & 0.18 & 0.06 \\
\hline Percent area of included bark & 88 & 0.07 & 106 & $\mathrm{~N} / \mathrm{A}^{\mathrm{w}}$ & 87 & 0.08 & $\mathrm{~N} / \mathrm{A}^{\mathrm{w}}$ \\
\hline Mean & & 0.22 & & 0.29 & & 0.29 & \\
\hline
\end{tabular}

${ }^{\mathrm{z}}$ Measured inside bark.

${ }^{\mathrm{y}}$ Measured above the attachment.

${ }^{\mathrm{x}}$ Measured below the attachment.

${ }^{\mathrm{w}}$ Only one callery pear had included bark.

sons that violated this assumption, Welch's ANOVA was used. Tukey's honestly significant difference test was used to separate means within each classification variable. Form of attachment and the presence of included bark were not analyzed for pears because only one attachment was classified as v-shaped and had included bark. Within each species, breaking stress was plotted against each of the morphologic measures that described the
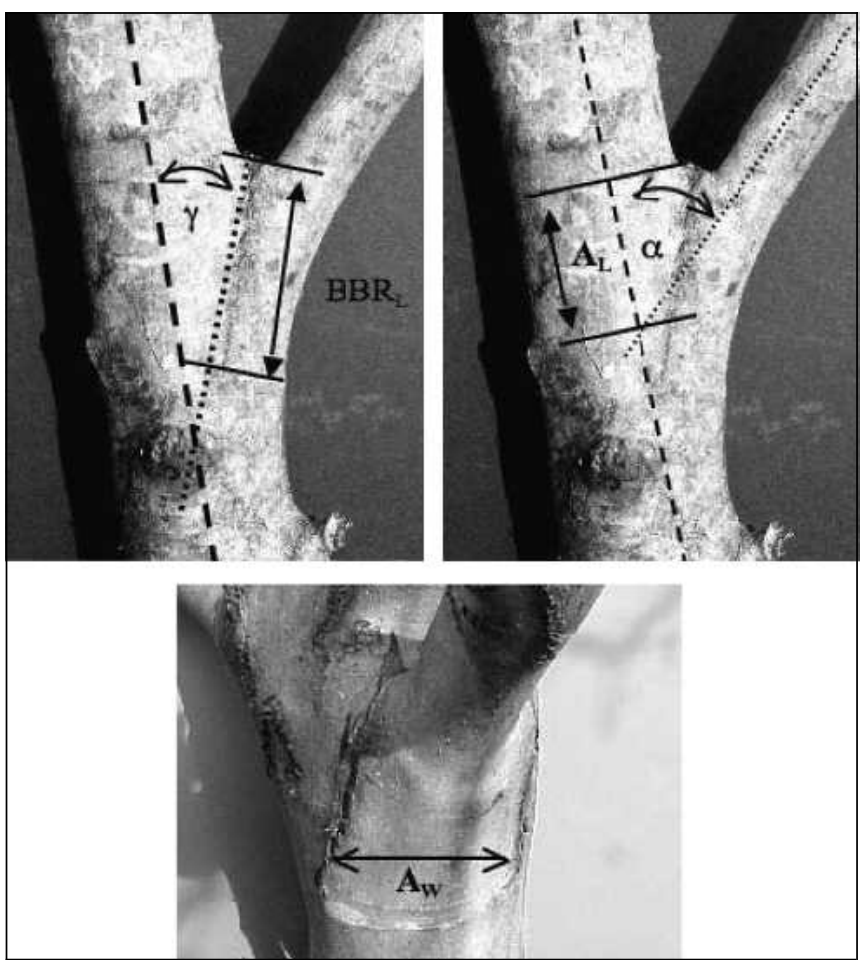

Figure 3. Diagram of various morphologic measurements that described the attachment. $A_{L}$ is the length of the attachment; $B B R_{L}$ is the length of the branch bark ridge; $A_{W}$ is the width of the attachment; and $\alpha$ and $\gamma$ are, respectively, the angles of the attachment and branch bark ridge. attachment; scatter plots revealed linear relationships, and residual plots suggested adequate models. Linear regression was used to investigate which morphologic measures best predicted

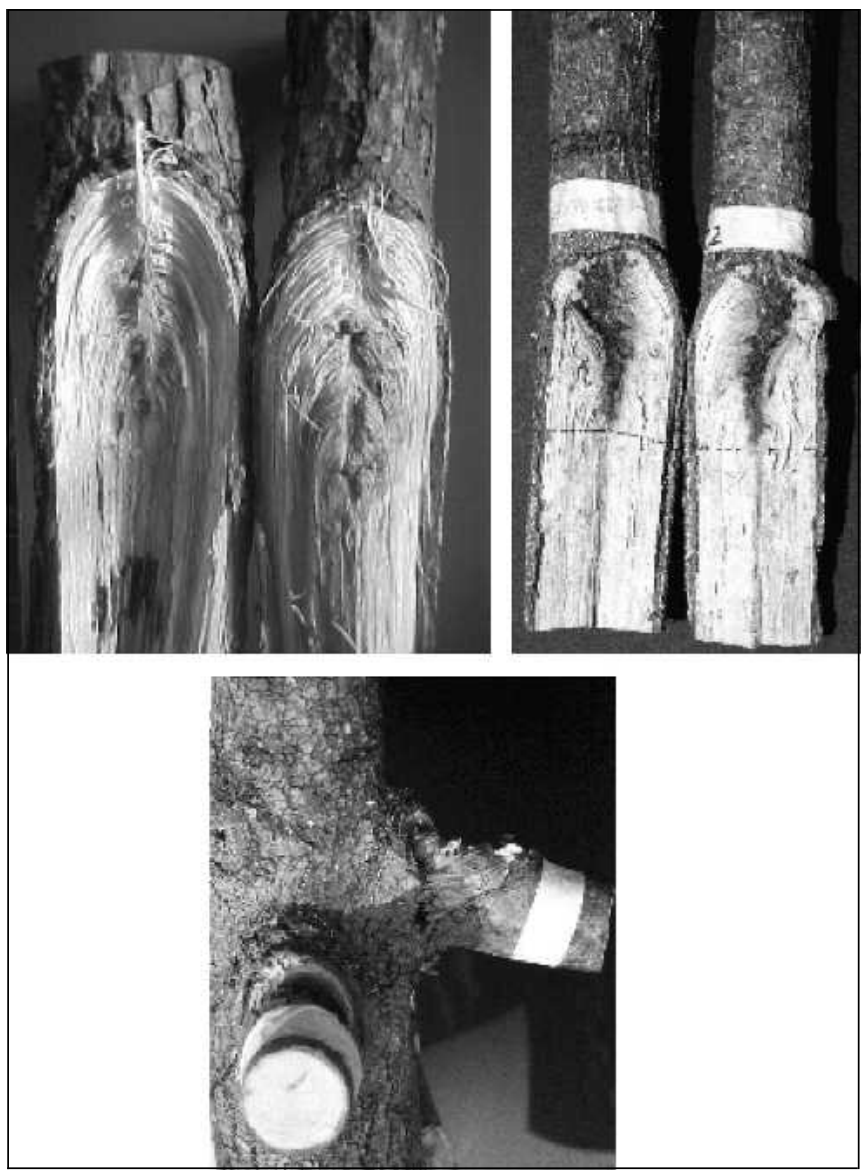

Figure 4. Examples of the three failure modes clockwise from top left: embedded branch failure on a white oak (not part of this study), flat surface failure on a sawtooth oak with included bark, ball in socket failure on a callery pear. 


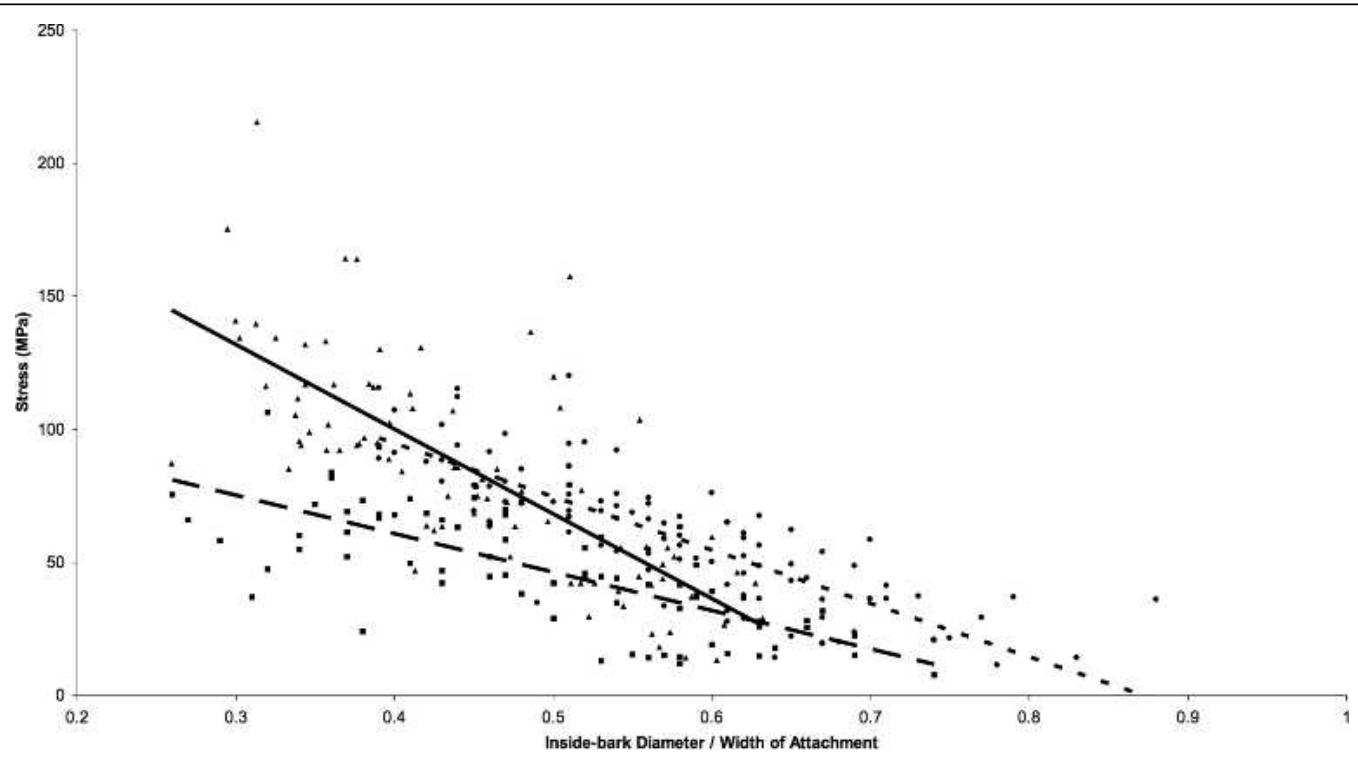

Figure 5. Scatterplots for the prediction of stress $(\sigma)$ from the ratio of inside-bark diameter and attachment width (ratio). Equations for best-fit lines were $\sigma=227-316^{*}$ ratio, $\sigma=175-200 *$ ratio, $\sigma=118-145 *$ ratio for sawtooth oak (solid line, $\Delta$ ), callery pear (dotted line, $\bullet$ ), and red maple (dashed line, $\square$ ), respectively. Slopes and intercepts were significant $(P<0.01$ ); the axes do not intersect at 0 .

breaking stress. Coefficients of determination were used to rank which morphologic measures best predicted breaking stress within each species, and the mean coefficient of determination across all species for a particular measure was used to determine the overall best predictors.

\section{RESULTS}

\section{Breaking Stress}

For each species, breaking stress was best predicted by one of two morphologic measures that described the attachment: diam- eter ratio and the ratio of inside-bark branch diameter to width of the attachment (Figures 5 and 6). Consequently, these two ratios had the highest mean coefficients of determination across all species (Table 1). Both ratios were negatively correlated to breaking stress for all species. In general, ratios of branch to trunk size were better predictors than angles and dimensions of the attachment itself (Table 1). The ratio of trunk diameter above the attachment to width of the attachment was somewhat reliable for all species, but its average coefficient of determination for all species was less than 0.50 , primarily because it was a less reli-

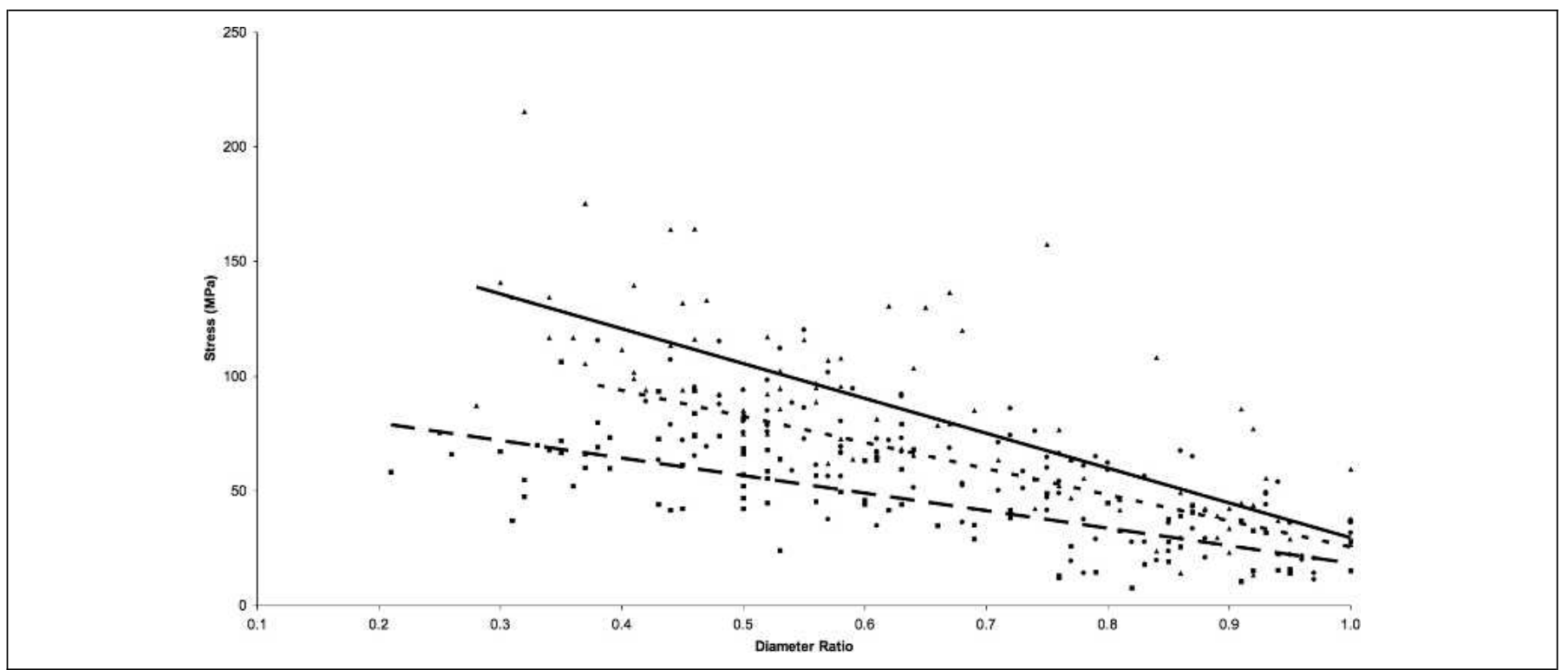

Figure 6. Scatterplots for the prediction of stress $(\sigma)$ from the ratio of branch diameter to trunk diameter (ratio). Equations for best-fit lines were $\sigma=181-152{ }^{*}$ ratio, $\sigma=139-114{ }^{*}$ ratio, $\sigma=94.8-76.3{ }^{*}$ ratio for sawtooth oak, (solid line, $\Delta$ ), callery pear (dotted line, $\odot$ ), and red maple (dashed line, $\square$ ), respectively. Slopes and intercepts were significant $(P<0.01$ ); the axes do not intersect at 0 . 
able predictor of breaking stress for red maple (Table 1). Branch diameter was a reliable predictor of breaking stress (average coefficient of determination for all species $=0.50$ ), but this was an artifact of Equation 1 and thus not included in Table 1. The percentage of attachment area covered by included bark did not influence breaking stress for red maple and sawtooth oak, the two species for which there were sufficient attachments to test the effect of included bark (Figure 7). This finding contradicted the finding that red maple and sawtooth oak had significantly stronger attachments when included bark was not present (Table 2).

It is important to point out the differences among species with respect to other predictors, aside from the two best. For example, length of the branch attachment and length of the branch bark ridge were somewhat reliable predictors of breaking stress for callery pear, but not for red maple or sawtooth oak (Table 2). Conversely, branch angle and branch bark ridge angle were somewhat reliable predictors of breaking stress for callery pear and sawtooth oak, but not for red maple.

\section{Attachment Type}

For all species, trunk-branch attachments were the most common and the strongest (Table 2). Branch-branch attachments were the least common for all species; for red maple, they were stronger than codominants, but this was not true of callery pear and sawtooth oak (Table 2). For all species, diameter ratio was significantly smaller (i.e., the branch was comparatively smaller than the trunk) for trunk-branch attachments than for branchbranch and codominant attachments (Table 2).

\section{Attachment Form and Included Bark}

For red maple and sawtooth oak, u-shaped attachments were stronger than v-shaped attachments (Table 2). Diameter ratio was greater for $\mathrm{v}$-shaped attachments of sawtooth oak, but this was not true of red maple (Table 2). Included bark was present in all of the v-shaped attachments on sawtooth oak and 17 of 18 v-shaped attachments on red maple. The presence of included bark was closely associated with form of the attachment in red maple (Table 2). This was not true of sawtooth oak; many ushaped attachments also had included bark. Attachments with included bark were not as strong as those without included bark (Table 2). For sawtooth oak, diameter ratio was greater for attachments with included bark, but this was not true of red maple (Table 2).

\section{Failure Mode and Included Bark}

For all species, ball and socket failures required the greatest breaking stress, whereas flat surface failures required the least (Table 2). Breaking stress of embedded branch failures was about midway between that of the other modes of failure, but the comparisons were not as robust for callery pear and sawtooth oak (Table 2). Branch diameter averaged $45 \%$ of trunk diameter for ball and socket failures of red maple and $57 \%$ of trunk diameter for callery pear and sawtooth oak. These diameter ratios were smaller than for flat surface failures, the branch diameter of which was approximately $90 \%$ of trunk diameter for all species (Table 2). Diameter ratio of embedded branch failures was closer to that of flat surface failures, but still significantly different from the other modes of failure for all species (Table 2). When data from all species were pooled together, the mode of failure was clearly related to diameter ratio; an apparent threshold diameter ratio occurred at 0.70 . At smaller diameter ratios, failures were almost exclusively ball and socket failures; when diameter ratio met or exceeded 0.70 , however, failures were almost exclusively flat surface and embedded branch (Figure 8).

\section{DISCUSSION}

The results largely agree with previous studies that diameter ratio was negatively correlated to and a better predictor of breaking stress than branch angle. Branch angle was also correlated with diameter ratio $\left(\mathrm{R}^{2}=0.23, P<0.01\right)$, which agrees with Miller's (1959) explanation as to why MacDaniels (1923) had

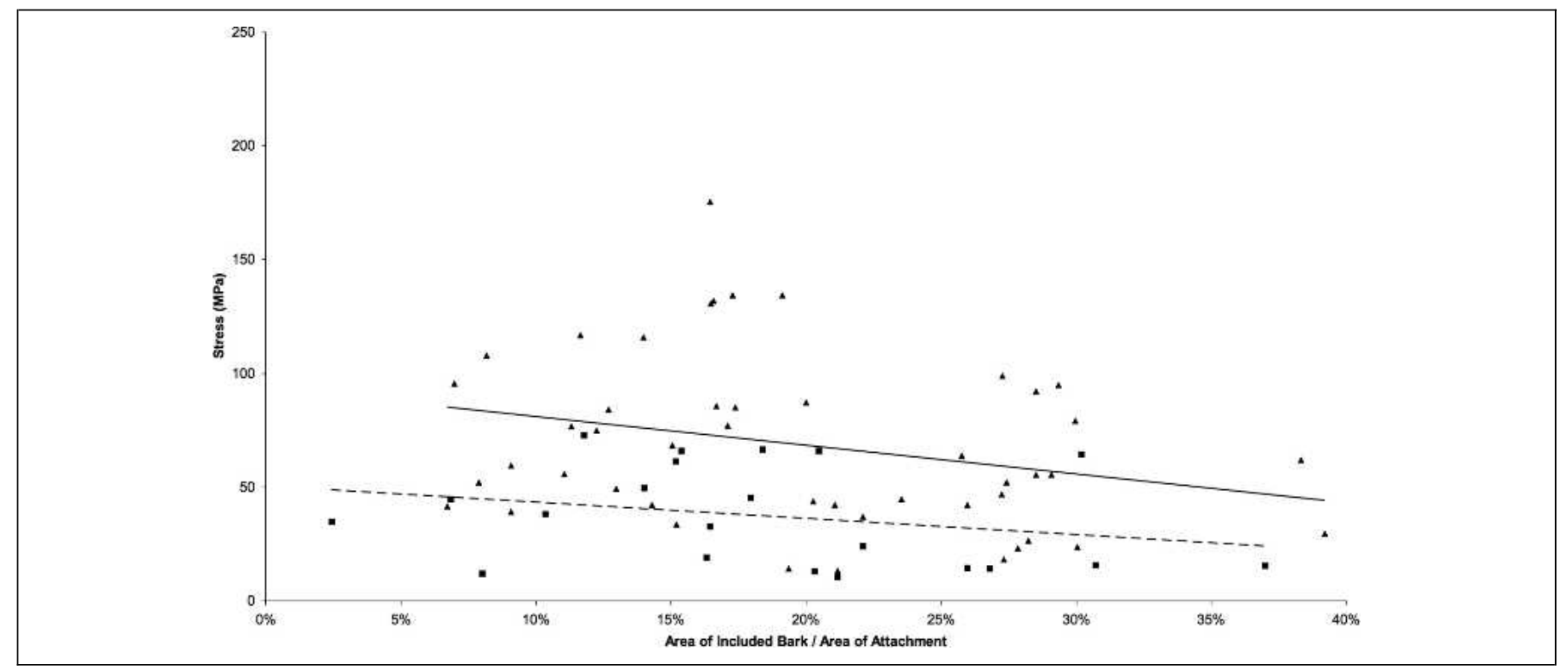

Figure 7. Scatterplots for the prediction of stress $(\sigma)$ from the percent of attachment area covered by included bark (area). Equations for best-fit lines were $\sigma=-126^{*}$ area +93.4 and $\sigma=-71.1^{*}$ area +50.3 for sawtooth oak (solid line, $\Delta$ ) and red maple (dashed line, $\square)$. Intercepts were greater than $0(P<0.01)$, but slopes were not $(P>0.05)$. 


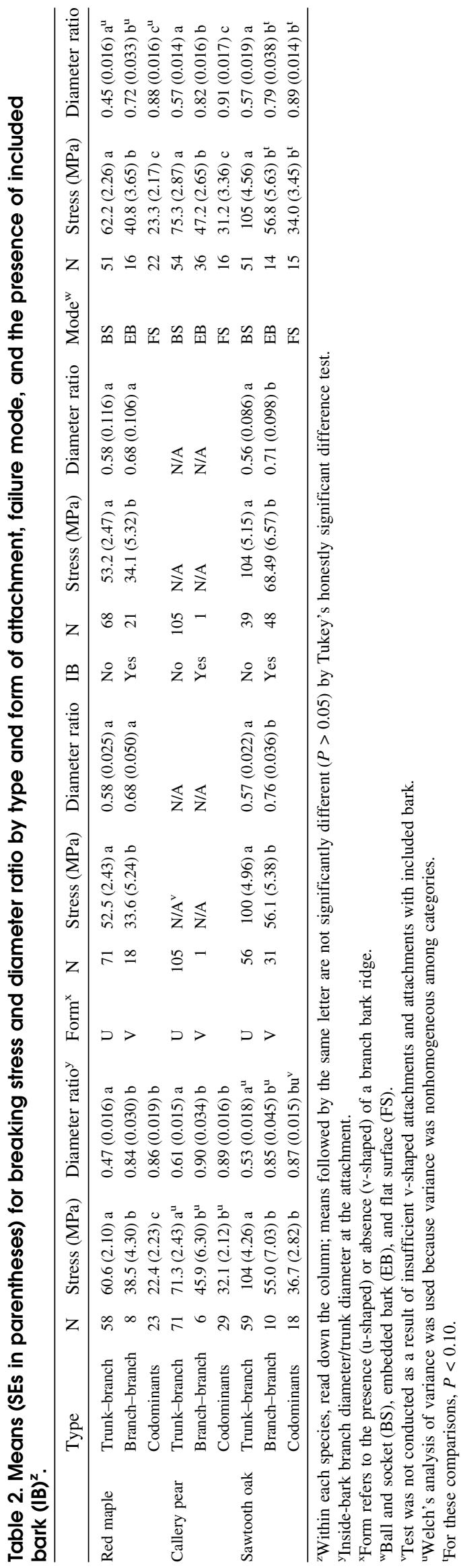

considered branch angle a reliable predictor of breaking stress. The more complete list of morphologic variables and ratios considered in the current study lends additional confidence that diameter ratio is the most reliable predictor of breaking stress for a range of species. It was also satisfying that this simple ratio was a better predictor of breaking stress than other ratios of branch and trunk size, because diameter ratio is easy to measure and calculate in the field. The ratio of branch diameter to width of the attachment reflects the diameter ratio, so it was not surprising that it was a similarly reliable predictor of breaking stress.

Both diameter ratio and the ratio of inside-bark branch diameter to width of the attachment reliably predicted breaking stress because as the size of the branch increases relative to the size of the trunk, xylem of the branch and trunk do not grow in the overlapping fashion diagrammed by Shigo (1985; Figure 6). Consequently, the branch is only attached to the trunk by the branch fibers directly below the point of attachment parallel to the trunk. Kane and Clouston's (2008) finding that codominant trunks were roughly one-half as strong as a single trunk supports this idea, as does Pfisterer's (2003) suggestion that the sum of the cross-sectional area of the trunk and branch above the attachment were equal to the cross-sectional area of the trunk below the attachment.

Despite its comparatively superior performance, however, diameter ratio still only predicted, on average, $57 \%$ of the observed variance in breaking stress for all species. This was similar to the coefficient of determination (0.56) reported by Gilman (2003) for the breaking stress of small red maple branches, but substantially greater than the value (0.19) reported by Kane (2007) for Bradford pears. Clearly, other variables affect the strength of branch attachments, but it does not appear that obvious external morphologic characteristics are among them.

An internal factor that may be expected to predict breaking stress of an attachment is wood strength or modulus of rupture (MOR). Although MOR was not considered in the current study, a useful surrogate, specific gravity, was examined. Previous studies have demonstrated the effect of wood properties on likelihood of tree failure (Putz et al. 1983; Jim and Liu 1997; Francis 2000), but specific gravity was not a reliable predictor of breaking stress within a species in the current study. This was likely the result of the limited intraspecies range of specific gravity and the fact that the relationship between specific gravity and MOR has been established on clear, defect-free wood samples (Green et al. 1999), not branches. Specific gravity was, however, a significant and somewhat reliable predictor $\left(\mathrm{R}^{2}=0.23, P<\right.$ 0.01 ) of breaking stress when species were pooled together. This finding, however, contradicted Lilly and Sydnor (1995), who reported no effect of wood strength with respect to branch failures of Norway (Acer platanoides L.) and silver (Acer saccharinum L.) maples, and Hauer et al. (1993) who found no effect of wood properties on the likelihood of tree failure after an ice storm.

It was not easy to explain the paradoxic findings that although breaking stress was greater in the absence of included bark, the percent of area of the attachment covered by included bark was not a reliable predictor of breaking stress. Although he did not quantify the amount of included bark, Smiley (2003) reported that the presence of included bark was always revealed in the plane of failure and reduced the breaking force of codominant stems of red maple. Kane and Clouston (2008) also observed that 


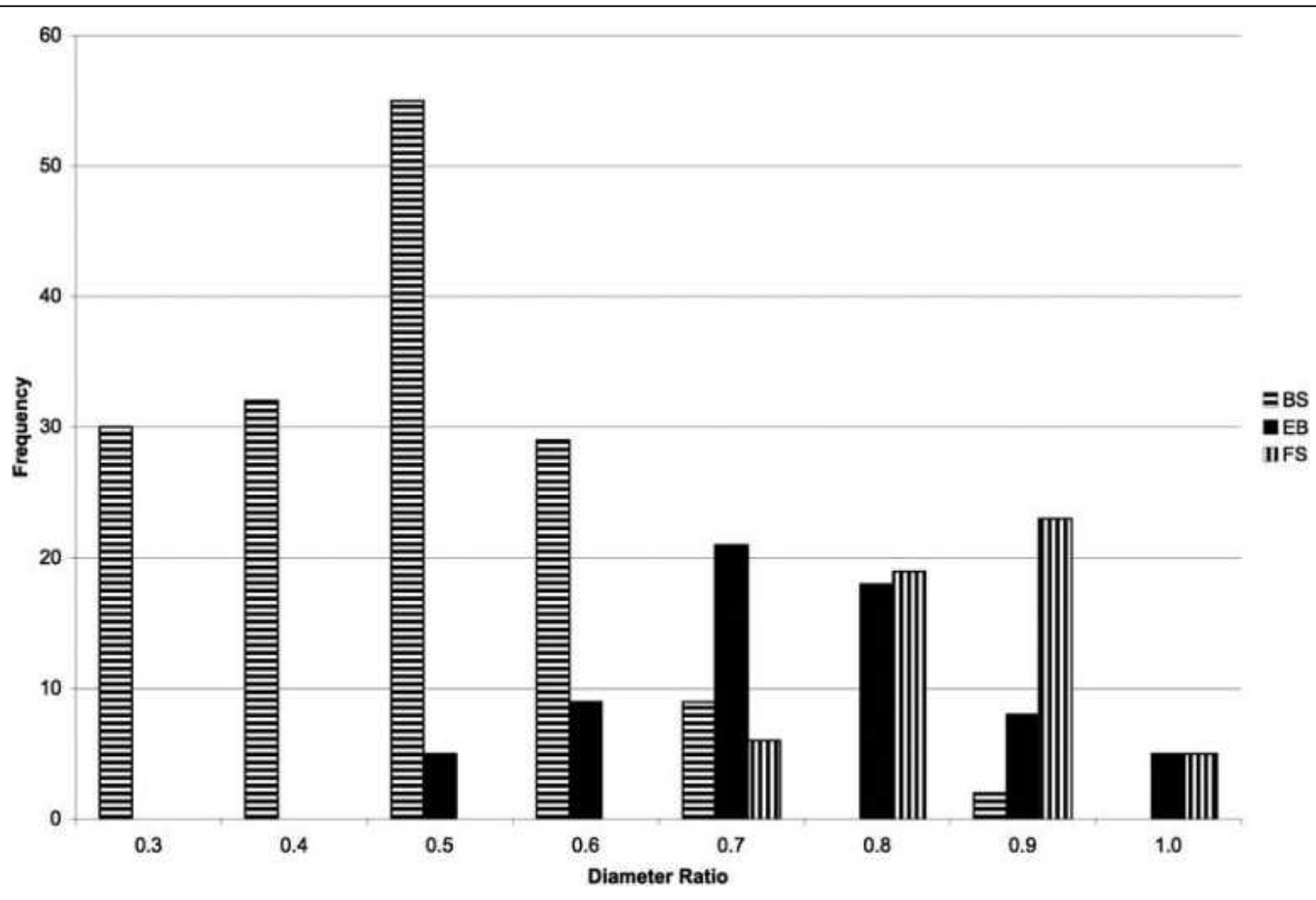

Figure 8. Frequency table of failure modes (ball and socket (BS), embedded bark (EB), and flat surface (FS)) for all species by diameter ratio.

codominant failures of large maples exposed included bark. Only one codominant failure in their study did not have included bark, and it was much stronger than the others (Kane and Clouston 2008). This was not true of sawtooth oak, for which only onethird of attachments with included bark failed at the plane of included bark. Because the area of included bark found in attachments was always less than $40 \%$ of the area of the attachment (the mean was $18 \%$ and $20 \%$ for red maple and sawtooth oak, respectively) and, in most failures, it was confined to a narrow strip in the center of the attachment that did not extend to the most recent growth rings, it may be that a threshold amount of included bark is necessary to weaken the attachment. An additional factor is the smaller range of the percentage of area of included bark (Figure 7), which limited the ability to predict from this variable. Perhaps a more illustrative measurement would have been the thickness of sound wood between included bark and the adaxial surface of the attachment, because, for a single attachment in a Norway spruce (Picea abies [L.] Karst.), strain was greatest at the adaxial surface of the attachment (Muller et al. 2006). It is also possible that the presence of included bark can weaken attachments but that the effect of diameter ratio supersedes it.

Using the form of an attachment as a surrogate for diameter ratio appeared to be reasonable for red maple and sawtooth oak, as reflected in the strength differences between $\mathrm{u}$ - and v-shaped attachments for those species. It was unexpected, however, that diameter ratios differed between $\mathrm{u}$ - and v-shaped attachments for sawtooth oak, but not for red maple. It was quite unexpected to find only a single $\mathrm{v}$-shaped attachment on callery pear, but this may be an artifact of the way the form of an attachment was characterized. The presence of a branch bark ridge on almost all callery pears was not associated with small-diameter ratios as it was for sawtooth oak, although the range of branch and attach- ment angles was similar for both species. This observation, as well as the finding that the rank order of predictors of breaking stress was not exactly the same for all species, highlights the effect of species on which morphologic measure(s) should be used in the field to determine tree risk.

Description of the three modes of failure is consistent with Figures 6, 7, and 9 in MacDaniels (1923), which show, as classified in the current study, flat surface, embedded bark, and ball and socket failures, respectively. The modes of failure corresponded quite well with diameter ratios, which further supports the idea that relatively large branches have comparatively less overlapping of branch and trunk fibers in the attachment (Shigo 1985). This is illustrated clearly in Figure 4: ball and socket failures show a substantial amount of trunk fibers pulled from the trunk as the attachment failed. Embedded branch failures show fewer trunk fibers pulled away from the trunk, and flat surface failures reveal, essentially, two trunks because the fibers of each are intact and parallel after failure. Flat surface failures resembled codominant failures of large maples described by Kane and Clouston (2008), except that failures always revealed included bark if it was present. Kane and Clouston (2008) speculated that failure of codominant stems was initiated in a complex stress state of shear and tension perpendicular to the grain at the attachment, which agrees with observations in the current study. Thus, the size of the attachment appears to be irrelevant in predicting the strength loss of the attachment.

Breaking stress of callery pear was somewhat less than previous findings for Bradford pear (Kane 2007), which may be the result of actual differences among the respective populations of trees. It is not possible to confirm this because of methodological and, possibly, cultivar differences. Although diameter ratio was similarly a reliable predictor of breaking stress for red maples tested by Gilman (2003), the breaking stress Gilman (2003) 
reported was considerably less than reported here. That disparity may be the result of Gilman (2003) testing much smaller branches, consisting predominantly of juvenile wood. There have been no previous studies of the strength of branch attachments of sawtooth oak. Pfisterer's (2003) report of longer durations of failure for narrow attachments compared with wide attachments of hazel (Corylus avellana L.) was not observed in the current study for any species.

\section{CONCLUSIONS}

Although the results from this and previous studies on predicting breaking stress largely agree on the importance of the ratio of branch to trunk diameter, the lack of strong coefficients of determination undermines one's ability to predict failure with certainty. Similarly, predicting breaking stress or the likelihood of failure from intuitively obvious factors such as inherent wood strength has also proved to be only somewhat reliable and species-dependent. In light of these ideas, arborists and urban foresters should conservatively assess tree risk with respect to branch attachment strength. In the field, practitioners should consider the strength of codominant stems and attachments where branch diameter is roughly $70 \%$ of trunk diameter to be roughly one-half as strong as an attachment that includes a clearly subordinate branch.

Acknowledgements. We thank two anonymous reviewers for sug-gesting helpful changes to earlier drafts of this manuscript.

\section{LITERATURE CITED}

Francis, J.K. 2000. Comparison of hurricane damage to several species of urban trees in San Juan, Puerto Rico. Journal of Arboriculture 26:189-197.

Gilman, E.F. 2003. Branch-to-stem diameter ratio affects strength of attachment. Journal of Arboriculture 29:291-294.

Green, D.W., J.E. Winandy, and D.E. Kretschmann. 1999. Mechanical properties of wood. In: Wood Handbook-Wood as an Engineering Material. Gen. Tech. Rep. FPL-GTR-113. USDA Forest Service Forest Products Laboratory, Madison, WI. 463 pp.

Hauer, R.J., W. Wang, and J.O. Dawson. 1993. Ice storm damage to urban trees. Journal of Arboriculture 19:187-194.

Jim, C.Y., and H.H.T. Liu. 1997. Storm damage on urban trees in Guangzhou, China. Landscape and Urban Planning 38:45-59.

Kane, B. 2007. Branch strength of Bradford pear (Pyrus calleryana var. 'Bradford'). Arboriculture and Urban Forestry 33:283-291.

Kane, B., and P. Clouston. 2008. Tree pulling of large shade trees in the genus Acer. Arboriculture and Urban Forestry 34:101-109.

Lilly, S., and T.D. Sydnor. 1995. Comparison of branch failure during static loading of silver and Norway maples. Journal of Arboriculture 21:302-305.

MacDaniels, L.H. 1923. The Apple-Tree Crotch. Bulletin 419. Cornell University Agricultural Experiment Station, Ithaca, NY. 22 pp.

- 1932. Factors affecting the breaking strength of apple tree crotches. Journal of the American Society for Horticultural Science 29:44.

Miller, V.J. 1959. Crotch influence on strength and breaking point of apple tree branches. Journal of the American Society for Horticultural Science 73:27-32.

Muller, U., W. Gindl, and G. Jeronimidis. 2006. Biomechanics of a branch-stem junction in softwood. Trees (Berlin) 20:643-648.
Pfisterer, J.A. 2003. Towards a better understanding of tree failure: Investigations into bending stresses of branch junction and stems of hazel (Corylus avellana L.) as a model organism. MitteilungenBiologischen Bundesanstalt fur Land und Forstwirtschaft 394: 272-279.

Putz, F.E., P.D. Coley, K. Lu, A. Montalvo, and A. Aiello. 1983. Uprooting and snapping of trees: Structural determinants and ecological consequences. Canadian Journal of Forest Research 13:1011-1020.

Shigo, A.L. 1985. How branches are attached to tree trunks. Canadian Journal of Botany 63:1391-1401.

Simpson, W., and A. TenWolde. 1999. Physical properties and moisture relations of wood. In: Wood Handbook-Wood as an Engineering Material. Gen. Tech. Rep. FPL-GTR-113. USDA Forest Service Forest Products Laboratory, Madison, WI. 463 pp.

Smiley, E.T. 2003. Does included bark reduce the strength of codominant stems? Journal of Arboriculture 29:104-106.

Smiley, E.T., C.M. Greco, and J.G. Williams. 2000. Brace rods for codominant stems: Installation location and breaking strength. Journal of Arboriculture 26:170-176.

Brian Kane (corresponding author)

University of Massechusettes-NRC

126 Holdsworth Hall

Amherst, MA 01003, U.S.

bkane@nrc.umass.edu

Robert Farrell

Virginia Department of Forestry

Rob.Farrell@dof.virginia.gov

Shepard M. Zedaker

Professor

Department of Forestry

Virginia Tech University

Blacksburg, Virginia

J.R. Loferski

Professor

Department of Wood Science and Forest Products

Virginia Tech University

Blacksburg, Virginia

D.W. Smith

Shelton H. Short Jr. Professor Emeritus

Department of Forestry

Virginia Tech University

Blacksburg, Virginia 
Résumé. Prédire la solidité d'attache des branches est important pour les arboriculteurs et les forestiers urbains parce que le bris d'une branche peut causer des dommages et des blessures. Les études antérieures ont démontré que le ratio entre le diamètre de la branche et celui du tronc est un meilleur facteur de prédiction que l'angle d'attache. À part ces deux facteurs, peu d'autres mesures morphologiques reliées à l'attache de la branche ont été analysées en regard de la prédiction de la solidité du point d'attache. Plusieurs points d'attache de branches de trois espèces ont été brisées au moyen d'une machine d'essai et le point de rupture a été calculé. Avant les essais de bris, diverses mesures morphologiques et des ratios descriptifs relatifs au point d'attache ont été recueillis. Le point de rupture variait en fonction de la forme de l'attache (fourche en $\mathrm{U}$ ou fourche en V), le mode de bris et la présence d'écorce incluse. Le meilleur facteur de prédiction du point de rupture était le ratio entre le diamètre de la branche et celui du tronc. Les résultats sont discutés dans le contexte des études antérieures et en fonction de l'évaluation du degré de risque.

Resumen. La predicción de la resistencia de las uniones de las ramas con los troncos es importante para los arboristas y dasónomos urbanos porque su falla puede causar daños y lesiones. Los estudios previos han mostrado que la relación entre el diámetro del tronco y la rama es un mejor indicador de esa fuerza que el ángulo de unión mismo. Aparte de estos dos factores, sin embargo, pocas medidas morfológicas extras han sido investigadas con respecto a la predicción de la resistencia de la unión. Se rompieron muchas uniones de ramas con troncos, en árboles de tres especies, empleando una máquina y se calculó el estrés de rotura. Antes de la falla, se hicieron varias mediciones morfológicas y relaciones. El estrés de rotura varió por la forma de la unión (forma de $\mathrm{u}$ o forma de v), modo de falla, y la presencia de corteza incluida. El mejor predictor del estrés de rotura fue la relación de diámetro de rama y de tronco. Los resultados son discutidos en el contexto de estudios previos y con respecto a la evaluación del riesgo de los árboles.
Zusammenfassung.Für urbane Forstleute und Arboristen ist es wichtig, die Stärke von Astanbindungen vorauszusehen, denn ein Versagen kann zu Unfällen und Verletzungen führen. Frühere Studien haben gezeigt, dass das Verhältnis von Ästen zum Baumdurchmesser eine bessere Vorhersage ist als der Winkel der Anbindung, Neben diesen zwei Faktoren wurden noch ein paar andere, morphologische Messungen dieser Anbindungen in Hinsicht auf eine Vorhersage der Stärke dieser Anbindung untersucht. Viele Astverbindung von drei Baumarten wurden mittels einer Maschine gebrochen und der Lasteintrag bis zum Abbrechen gemessen. Vor dem Brechen wurden verschiedene morphologische Messungen und Verhältnisse der Anbindung erhoben. Die Belastung variierte durch die Form der Anbindung (rund oder V-förmig), Art des Brechens und der Beteiligung von Rinde. Die beste Vorhersage war das Verhältnis von Ast zum Stammdurchmesser. Die Resultate werden im Zusammenhang mit den früheren Studien und der Baumdiagnose diskutiert. 